\title{
PLANTS
}

\section{OBSERVATIONS ON THE FLOWERING OF DECIDUOUS TREES AND SHRUBS IN REGINA, SK}

H.E. MANN, Biology Department, Sir Wilfred Grenfell College, Memorial University of Newfoundland, Corner Brook, NF, A2H 6P9 and M.V.S. RAJU, George Ledingham Herbarium, Biology Department, University of Regina, Regina, SK, S4S OA2

In the last thirty years, the composition of the flora of the prairie city of Regina, located in south central Saskatchewan $\left(50^{\circ} 27^{\prime} \mathrm{N}, 104^{\circ} 37^{\prime} \mathrm{W}\right.$ ) has changed considerably due to the planting of many trees and shrubs, both native (indigenous) and introduced (nonindigenous) ${ }^{2,5}$ Almost all woody plants in the city have been planted except a few native species that occur along shores of wetlands such as Wascana Creek. Many species would not be able to establish themselves as seedlings on the dry open prairie, but once planted, established, and cared for by irrigation and fertilization, are able to flourish and enhance the quality of urban life. Over the years, as new species were introduced, it seemed interesting to follow their growth and to compare them to the already existing species. This article describes some of these observations on deciduous trees and shrubs, specifically with reference to their flowering phenology.

Observations of flowering behaviour of deciduous trees and shrubs were made within the city limits of Regina and especially on the campus of the University of Regina. The area selected for the study was comprised of open, abandoned areas, and streets and parks, including Wascana Park where the campus of the University of Regina is situated. Deciduous trees and shrubs, including some wild species along the shores of Wascana creek, were identified using available floras and guides. ${ }^{4,6,7}$ Bailey's publication was also consulted for more exotic introductions, such as Tamarisk, Mongolian Linden, etc. ${ }^{1}$ Every year since 1970 , trees and shrubs were periodically monitored throughout the growing season from mid-March to late-August and details of flowering were recorded.

Table 1 summarizes the observations made on the 71 species (belonging to 38 genera and 19 families) included in this study. The terms "trees" and "shrubs" are variously used in the published literature and in some species the definitions may overlap. In this article, trees are considered to have one or a few main stems and to grow in excess of 4.5 meters, whereas shrubs have a number of branching stems and usually do not attain a height of 4.5 meters at maturity. We define "native" plants as those that have naturally occurred in the Regina Plain, Landscape Area 17 of the Moist Mixed Grassland ecoregion of Saskatchewan. ${ }^{5}$ With respect to time of flowering, many of the species in Table 1 have been observed and recorded since 1970, but the data 
Table 1 List of tree and shrub species with in city limits of Regina showing whether they are native (NAT) or introduced (INT), time of flowering and other phenologial characters.

\begin{tabular}{|c|c|c|c|c|c|c|c|c|}
\hline No. & $\begin{array}{l}\text { Plant } \\
\text { Family }\end{array}$ & Plant name (Latin) & $\begin{array}{l}\text { Common } \\
\text { name }\end{array}$ & $\begin{array}{l}\text { Tree } \\
\text { (T) or } \\
\text { Shrub } \\
(\mathrm{S}) \\
\end{array}$ & $\begin{array}{l}\text { Introduced } \\
\text { (1NT) or } \\
\text { Native } \\
\text { (NAT) }\end{array}$ & $\begin{array}{l}\text { Flower } \\
\text { early }\end{array}$ & $\begin{array}{l}\text { Flower } \\
\text { later }\end{array}$ & $\begin{array}{l}\text { Time of } \\
\text { flowering* }\end{array}$ \\
\hline 1 & Salicaceae & Populus alba L. & White Poplar & $\mathrm{T}$ & $1 \mathrm{NT}$ & + & - & Apr \\
\hline 2 & & P. balsamifera L. & Balsam Poplar & $\mathrm{T}$ & NAT & + & - & Apr-May \\
\hline 3 & & P. grandidentata Michx. & $\begin{array}{l}\text { Large-toothed } \\
\text { Aspen }\end{array}$ & $\mathrm{T}$ & INT & + & - & Apr-May \\
\hline 4 & & P. tremuloides Michx. & Aspen Poplar & $T$ & NAT & + & - & Apr-May \\
\hline 5 & & Salix alba L. & White Willow & $\mathrm{T}$ & INT & + & - & Apr-May \\
\hline 6 & & S. bebbiana Sarg. & Beaked Willow & $\mathrm{S}$ & NAT & + & - & Apr-May \\
\hline 7 & & S. brachycarpa Nutt. & $\begin{array}{l}\text { Short-capsuled } \\
\text { Willow }\end{array}$ & $S$ & NAT & + & - & Apr-May \\
\hline 8 & & S. discolor Muhl. & $\begin{array}{l}\text { Pussy Willow } \\
\text { or diamond } \\
\text { willow } \\
\end{array}$ & $\mathrm{S}$ & NAT & + & - & Mar-Apr \\
\hline 9 & & S. fragilis L. & Brittle Willow & $\mathrm{T}$ & INT & + & - & Apr-May \\
\hline 10 & & S. interior Rowlee & Sandbar Wiilow & $\mathrm{S}$ & NAT & \pm & - & Apr-May \\
\hline 11 & & S. lucida Muhl. & Shining Willow & $\mathrm{T}$ & NAT & + & - & Apr-May \\
\hline 12 & & S. lutea Nutt. & Yellow Willow & $\mathrm{S}$ & NAT & + & - & Apr-May \\
\hline 13 & & S. pentandra L. & $\begin{array}{l}\text { Bay-leaved } \\
\text { Willow }\end{array}$ & $T$ & INT & + & - & Apr-May \\
\hline 14 & Betulaceae & Alnus incana (L.) Moench & Speckled Alder & $\mathrm{T}$ & INT & + & - & Apr-May \\
\hline 15 & & Betula papyrifera Marsh. & White Birch & $\mathrm{T}$ & INT & + & - & Apr-May \\
\hline 16 & Fagaceae & $\begin{array}{l}\text { Quercus } \\
\text { macrocarpa Michx. }\end{array}$ & Bur Oak & $\mathrm{T}$ & INT & + & - & May \\
\hline 17 & Ulmaceae & Celtis occidentalis $\mathrm{L}$. & Hackberry & $\mathrm{T}$ & INT & + & - & Apr-May \\
\hline 18 & & Ulmus americana $\mathrm{L}$. & American Elm & $\mathrm{T}$ & INT & + & - & Apr \\
\hline 19 & & U. chinensis & Chinese Elm & $\mathrm{T}$ & INT & + & - & Apr-May \\
\hline 20 & $\begin{array}{l}\text { Saxifrag- } \\
\text { aceae }\end{array}$ & Philadelphus lewisii Pursh. & Mock-Orange & $\mathrm{S}$ & INT & - & + & June \\
\hline 21 & & Ribes americanum Mill. & Black Currant & $\mathrm{S}$ & NAT & - & + & May \\
\hline 22 & & R. aureum Pursh & Golden Currant & $\mathrm{S}$ & NAT & - & + & May \\
\hline 23 & Rosaceae & $\begin{array}{l}\text { Amelanchier } \\
\text { alnifolia Nutt. }\end{array}$ & $\begin{array}{l}\text { Saskatoon- } \\
\text { berry }\end{array}$ & $\mathrm{S}$ & NAT & - & + & May-Jun \\
\hline 24 & & $\begin{array}{l}\text { Cotoneaster } \\
\text { acutifolia Turcz. }\end{array}$ & Cotoneaster & $\mathrm{S}$ & INT & - & + & May-Jun \\
\hline 25 & & $\begin{array}{l}\text { Crataegus } \\
\text { rotundifolia Moench }\end{array}$ & $\begin{array}{l}\text { Round-leaved } \\
\text { Hawthorn } \\
\end{array}$ & $\mathrm{S}$ & NAT & - & + & May-Jun \\
\hline 26 & & Malus sp. & $\begin{array}{l}\text { Apple } \\
\text { (Horticultural) }\end{array}$ & $\mathrm{T}$ & INT & + & - & May-Jun \\
\hline 27 & & M. spectabilis Borkh. & Crabapple & $\mathrm{T}$ & INT & - & + & Jun \\
\hline 28 & & $\begin{array}{l}\text { Physocarpus malvaceus } \\
\text { (Greene) Kuntze }\end{array}$ & $\begin{array}{l}\text { Mallow-leaved } \\
\text { Ninebark }\end{array}$ & $\mathrm{S}$ & INT & + & - & Jun \\
\hline 29 & & Potentilla fruticosa $\mathrm{L}$. & $\begin{array}{l}\text { Shrubby } \\
\text { Cinquefoil }\end{array}$ & $S$ & NAT & - & + & Jun-Aug \\
\hline 30 & & Prunus pennsylvanica $\mathrm{L}$. & Pin Cherry & $\mathrm{S}$ & NAT & - & + & May-Jun \\
\hline 31 & & P. tenella Batsch & $\begin{array}{l}\text { Russian } \\
\text { Almond }\end{array}$ & $\mathrm{S}$ & INT & + & - & May-Jun \\
\hline 32 & & P. virginiana $\mathrm{L}$. & Choke Cherry & $\mathrm{S}$ & NAT & - & + & May-Jun \\
\hline 33 & & Rosa acicularis Lindl. & Prickly Rose & $\mathrm{S}$ & NAT & - & \pm & Jun \\
\hline 34 & & R. arkansana Porter & $\begin{array}{l}\text { Low prairie } \\
\text { Rose } \\
\end{array}$ & $S$ & NAT & - & + & Jun \\
\hline 35 & & R. woodsii Lindl. & Wood's Rose & $\mathrm{S}$ & NAT & - & + & Jun \\
\hline 36 & & Sorbus americana Marsh. & $\begin{array}{l}\text { Western } \\
\text { Mountain-Ash }\end{array}$ & $\mathrm{T}$ & INT & - & + & May-Jun \\
\hline 37 & & Spiraea alba Du Roi & Meadowsweet & $\mathrm{S}$ & NAT & - & + & May \\
\hline 38 & & S. japonica L. & $\begin{array}{l}\text { Japanese } \\
\text { Spiraea } \\
\end{array}$ & $S$ & INT & - & + & Jun \\
\hline 39 & Fabaceae & Amorpha fruticosa $\mathrm{L}$. & False Indigo & $S$ & INT & - & + & Jun-Jul \\
\hline
\end{tabular}


Table 1 continued

\begin{tabular}{|c|c|c|c|c|c|c|c|c|}
\hline 40 & & $\begin{array}{l}\text { Caragana } \\
\text { arborescens Lam. }\end{array}$ & $\begin{array}{l}\text { Common } \\
\text { Caragana }\end{array}$ & $\mathrm{S}$ & INT & - & + & May-Jun \\
\hline 41 & & C. frutex Koch & Globe Caragana & $\mathrm{S}$ & INT & - & + & Jun \\
\hline 42 & & C. pygmea DC. & Caragana & $\mathrm{S}$ & INT & - & + & Jun \\
\hline 43 & Celastraceae & Euonymus nanus Bieb. & Spindle shrub & $\mathrm{S}$ & INT & - & + & Jun-Jul \\
\hline 44 & & E. atropurpureus Jacg. & Burning-bush & $\mathrm{S}$ & INT & - & + & Jun-Jul \\
\hline 45 & Anacardiaceae & Rhus radicans $\mathrm{L}$. & Poison-Ivy & $\mathrm{S}$ & NAT & - & + & Jun \\
\hline 46 & Aceraceae & Acer ginnala Maxim. & Amur Maple & $\mathrm{T}$ & INT & + & - & Jun \\
\hline 47 & & A. negundo $\mathrm{L}$. & Box Elder & $\mathrm{T}$ & NAT & + & - & Apr-May \\
\hline 48 & & A. saccharinum $\mathrm{L}$. & Silver Maple & $T$ & INT & + & - & Apr-May \\
\hline 49 & $\begin{array}{l}\text { Hippocasta- } \\
\text { naceae }\end{array}$ & Aesculus carnea Hayne & $\begin{array}{l}\text { Red Horse- } \\
\text { Chestnut }\end{array}$ & $T$ & INT & - & + & May-Jun \\
\hline 50 & $\begin{array}{l}\text { Tamarica- } \\
\text { ceae }\end{array}$ & Tamarix gallica L. & Tamarisk & $\mathrm{S}$ & INT & - & + & Jun-Aug \\
\hline 51 & Vitaceae & $\begin{array}{l}\text { Parthenocissus } \\
\text { quinquefolia (L.) Planch. }\end{array}$ & Virginia creeper & $\mathrm{S}$ & INT & - & + & Jun \\
\hline 52 & Rhamnaceae & Rhamnus alnifolia L'Hér. & $\begin{array}{l}\text { Alder-leaved } \\
\text { Buckthorn }\end{array}$ & $\mathbf{S}$ & NAT & + & - & Apr-May \\
\hline 53 & Tiliaceae & Tilia americana L. & Basswood & $\mathrm{T}$ & INT & - & + & Jun \\
\hline 54 & & T. europaea L. & $\begin{array}{l}\text { European } \\
\text { Linden }\end{array}$ & $T$ & INT & - & + & Jun \\
\hline 55 & & T. mongolica Maxim. & $\begin{array}{l}\text { Mongolian } \\
\text { Linden }\end{array}$ & $\mathrm{T}$ & INT & - & + & Jun \\
\hline 56 & $\begin{array}{l}\text { Elaeagna- } \\
\text { ceae }\end{array}$ & Elaeagnus angustifolia L. & Russian Olive & $T$ & INT & - & + & Jun \\
\hline 57 & & E. commutata Bernh. & Wolf Willow & $\mathbf{S}$ & NAT & - & + & May-Jun \\
\hline 58 & & Shepherdia argentea Nutt. & Buffaloberry & $\mathrm{S}$ & NAT & - & + & May-Jun \\
\hline 59 & Cornaceae & Cornus alba L. & $\begin{array}{l}\text { Red-Osier } \\
\text { Dogwood }\end{array}$ & $\mathrm{S}$ & NAT & - & + & May-Jun \\
\hline 60 & Oleaceae & Forsythia ovata Nakai. & Golden-bells & $\mathrm{S}$ & INT & + & - & May \\
\hline 61 & & $\begin{array}{l}\text { Fraxinus } \\
\text { pennsylvanica Marsh. }\end{array}$ & Green Ash & $\mathrm{T}$ & NAT & + & - & May \\
\hline 62 & & Syringa amurensis Rupr. & Japanese Lilac & $\mathrm{T}$ & INT & - & + & Jul \\
\hline 63 & & S. vulgaris L. & Lilac & $\mathbf{S}$ & INT & - & + & May-Jun \\
\hline 64 & $\begin{array}{l}\text { Caprifolia- } \\
\text { ceae }\end{array}$ & Sambucus racemosa $\mathrm{L}$. & Red Elderberry & $\mathrm{S}$ & INT & + & - & May-Jun \\
\hline 65 & & Lonicera tarlarica $\mathrm{L}$. & $\begin{array}{l}\text { Tartarian } \\
\text { Honeysuckle } \\
\end{array}$ & $\mathrm{S}$ & INT & - & + & May-Jun \\
\hline 66 & & $\begin{array}{l}\text { Symphoricarpos } \\
\text { albus (L.) Blake }\end{array}$ & Snowberry & $\mathrm{S}$ & NAT & - & + & Jun \\
\hline 67 & & S. occidentalis Hook & $\begin{array}{l}\text { Western } \\
\text { Snowberry }\end{array}$ & $\mathrm{S}$ & NAT & - & + & Jun \\
\hline 68 & & Viburnum acerifolium $\mathrm{L}$. & Dockmackie & $\mathrm{S}$ & INT & - & + & May-Jun \\
\hline 69 & & V. lentago L. & Nannyberry & $\mathrm{S}$ & INT & + & - & May-Jun \\
\hline 70 & & V. opulus L. & $\begin{array}{l}\text { European } \\
\text { bush-Cranberry } \\
\text { or High } \\
\text { bush-Cranberry }\end{array}$ & $\mathrm{S}$ & INT & - & + & Jun \\
\hline 71 & & V. trilobum Marsh. & $\begin{array}{l}\text { High Bush } \\
\text { Cranberry }\end{array}$ & $\mathrm{S}$ & NAT & - & + & Jun \\
\hline
\end{tabular}

Data presented are those recorded for the growing season of 1999. 
presented in Table 1 refer only to the observations made during the growing season of 1999 .

Of the 71 species identified in the study area, 27 (38\%) were trees and 44 $(62 \%)$ shrubs and there were more introduced species (62\%) than native $(38 \%)$ (Table 1). Among trees, there were more introduced $(81 \%)$ than native (19\%) species. By contrast, equal numbers of native and introduced shrub species were present.

Some species flower very early, before the leaves are produced or, in some, while the leaves are still immature. Others blossom later, after the leaves are fully formed. Most trees, both introduced and native, showed a tendency to flower earlier (70\%), before the leaves were formed, as compared to shrubs, $70 \%$ of which flowered after the leaves were formed. Most introduced $(77 \%)$ and native (64\%) shrubs leafed out well before the flowers appeared. The introduced shrubs bloomed late, extending the flowering period, and were probably selected for this aspect by horticulturists for aesthetic reasons.

Figure 1 summarizes in graphic format the seasonal flowering data for various combinations of trees and shrubs. In the study, the flowering time in deciduous trees and shrubs, despite fluctuations in their number, extended from late March to late August. Flowering in native trees began in April and remained dominant until about the middle of May. It abruptly declined in June. Flowering in introduced trees started in April and lasted until the end of July. The native shrubs, on the other hand, began to flower very early (midor late March) and extended until about the end of August, showing a peak in June. Flowering in the introduced shrubs lasted until the end of August.
Environmentalists and ecologists make a distinction between "native" and "introduced" plants and discuss their role in the ecosystem. ${ }^{3}$ In the present study area, $62 \%$ of the woody plant species (trees and shrubs) were introduced. "Introductions of nonindigenous organisms can be both a boon and a bane to society". ${ }^{3}$ World societies, especially in the temperate countries, depend heavily on introduced plants for their survival. ${ }^{3}$ Good examples of aggressive opportunism by plants may be seen in agricultural endeavours where the disturbance of the habitat has allowed many undesirable weeds to move in. Changes in ecosystems due to deliberate introductions and/or invasions of plants have been going on since time immemorial. It is important, however, to minimize deliberate introductions and carry out appropriate testing and research before full-scale use of exotics is initiated. Continued monitoring also is necessary to identify species which may have a tendency to become over-aggressive in their new environment. Woody species, which must survive the ravages of our prairie winters both above and below ground are, however, less likely to become weedy than annuals or herbaceous perennials and only a few have done so. The shrubs and trees, both native and introduced, together maintain a long flowering period and most are welcome additions for beauty of the landscape, shelter and wildlife sustenance.

There was an interesting note recently in a local newspaper about planting trees in Regina. ${ }^{8}$ The city of Regina has decided to introduce "a program to involve citizen volunteers in planting some 10,000 Bur Oak trees as a millennium project [which] is set to blossom, early in the New Year in Regina". This ambitious program is expensive, but it is, no doubt, welcome. The planting of Bur Oak trees in the 
Figure 1. Graphic representation of the flowering pattern of various deciduous woody plant groups during the growing season of 1999.

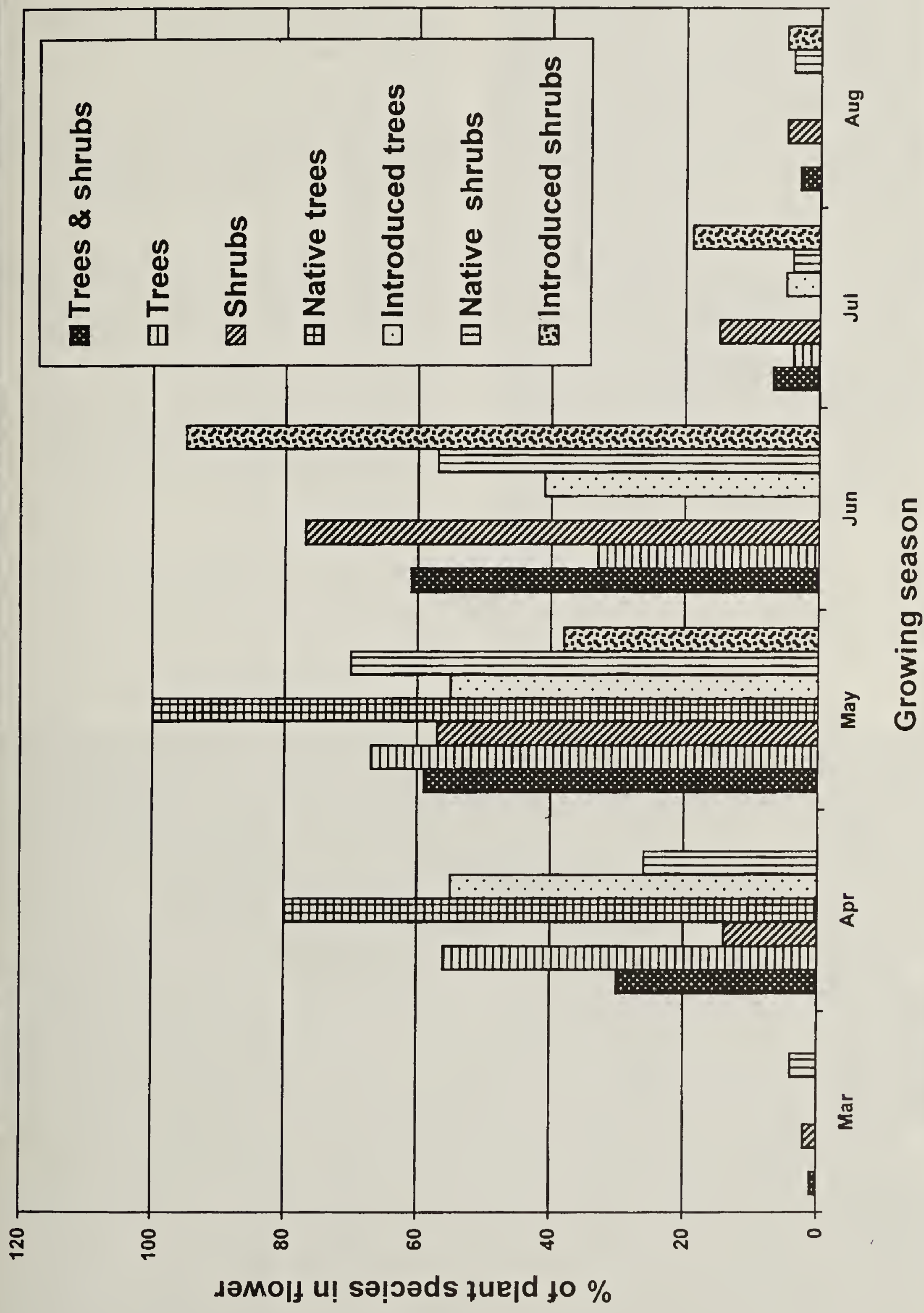


Regina area adds to the aesthetic beauty more because of their arboreal quality than because of their flowers, which are rather small, inconspicuous and short lived.

\section{Acknowledgements}

Authors are thankful to the reviewers for reading the manuscript critically and checking the plant names for accuracy.

1. Bailey, L. H. 1949. Manual of cultivated plants. Macmillan Company, Toronto.

2. City of Regina. 1999. Profile of our Capital City. (December 1999). www.cityregina.com

3. Ewell, J. et al. 1999. Deliberate Introduction of Species: Research Needs. BioScience 49:619-630.
4. Farrar, J. L. 1995. Trees in Canada. Fitzhenry \& Whiteside Limited and The Canadian Forest Service. Natural Resources Canada, Canada.

5. Fung, Ka-iu. 1999. Atlas of Saskatchewan. $2^{\text {nd }}$ Edition. University of Saskatchewan, Saskatoon.

6. Looman, J. and K.F. Best. 1979. Budd's Flora of the Canadian Prairie Provinces. Publication 1662. Supply and Services Canada, Hull, Quebec.

7. Moss, E. H. and J. G. Packer. 1983. Flora of Alberta. Revised edition. University of Toronto Press, Toronto.

8. Regina Leader Post. December 1, 1999. "Burr Oak program set to go", by Neil Scott). p. A7.

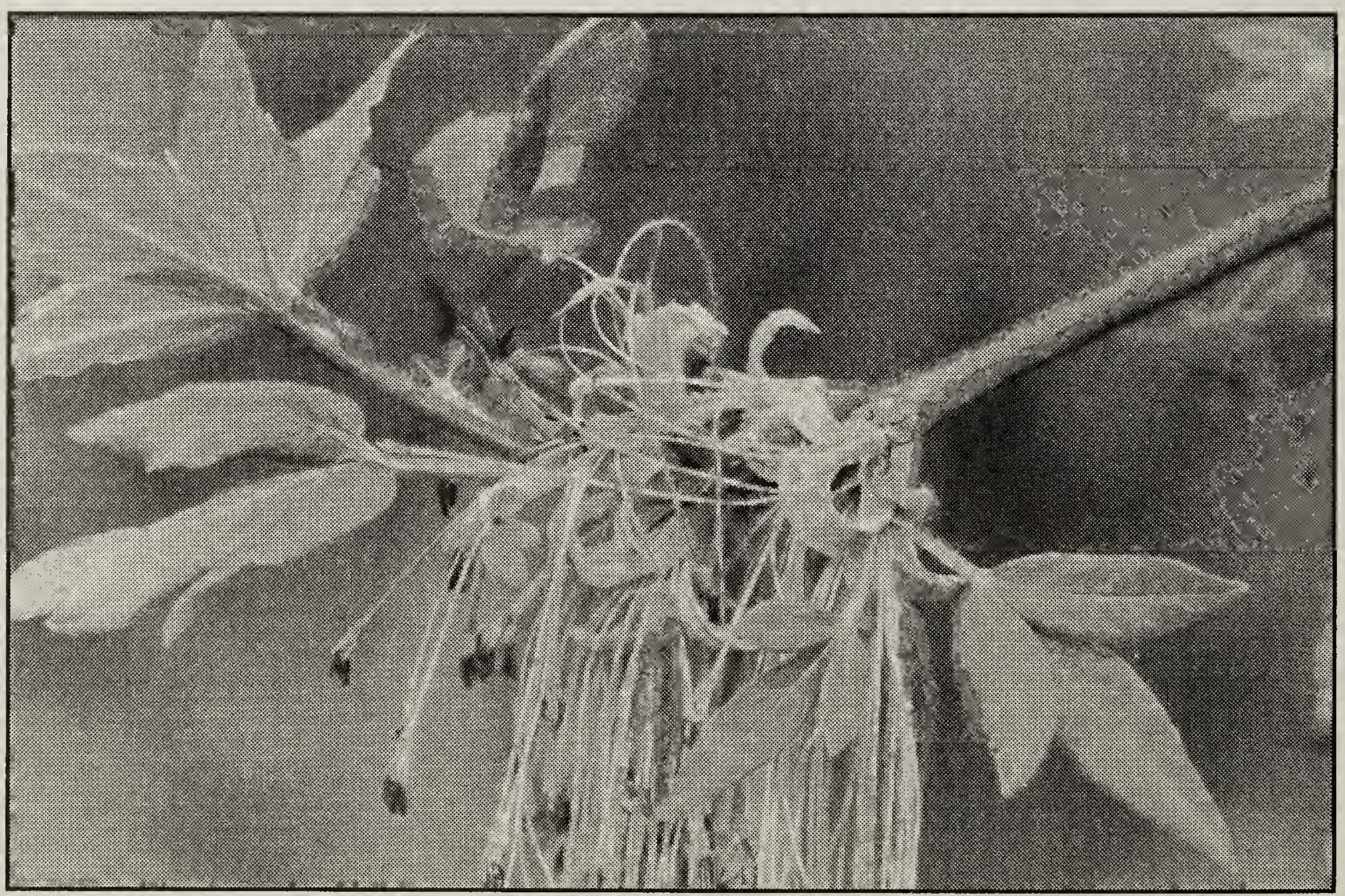

